\title{
Evaluation of Golgi Protein-73 as a Tumor Marker in Patients with Hepatocellular Carcinoma
}

\author{
Naglaa El-Toukhy ${ }^{1}$, Mona Youssef ${ }^{2}$, Hesham A Eissa ${ }^{3}$ \\ ${ }^{1}$ Department of Hepatology, Gastroenterology and Infectious Diseases, Faculty of \\ Medicine, Benha University, Egypt. \\ ${ }^{2}$ Department of Hepatology and Gastroenterology, Benha Teaching Hospital, Egypt. \\ ${ }^{3}$ Department of Clinical and Chemical Pathology, Faculty of Medicine, Benha \\ University, Egypt.
}

Corresponding Author Mona Youssef AbdEl-Rahman

Mobile:

$+01225529030$ E mail:
mona.yussef@yahoo.c
om

Key words:

Hepatocellular carcinoma; GP73; Alpha-fetoprotein
Background and study aim: Hepatocellular carcinoma (HCC) is the most common type of primary liver tumors. In Egypt, it is the second most common cancer in men, and the sixth most frequent cancer in women. Prognosis of HCC depends on tumor stage, with curative therapies effective only in early stage; thus, new and appropriate HCC markers are highly required. The aim was to evaluate serum diagnostic value Golgi Protein 73 in Egyptian HCC patients.

Patients and Methods: This study included $30 \mathrm{HCC}$ patients, 30 cirrhotic patients and 20 healthy controls. For all groups clinical data and imaging results were studied; serum alpha-fetoprotein and Golgi Protein 73 were identified.

Evaluation of the tumor characteristics including size, number and location. Okuda, CLIP and Tokyo staging methods used in tumor staging.

Results: GP73 was significantly higher in HCC patients compared to cirrhotic patients and controls. Its sensitivity and specificity in $\mathrm{HCC}$ diagnosis were $95 \%$ and $83.3 \%$, respectively, at cut-off $5.8 \%$. There is a positive correlation between GP73 and Okuda score and CIIP score and no correlations with number and size of the tumor, child's classification, MELD, uMELD and Tokyo stages.

Conclusion: GP73 could be a useful diagnostic marker for detection and screening of HCC.

\section{INTRODUCTION}

Hepatocellular carcinoma (HCC) constitutes $70 \%-90 \%$ of liver malignancy [1]. HCC is considered the second major cause of male malignancy death and the sixth in females worldwide [2]. HCC has elevated incidence in patients with chronic liver disease (CLD) and cirrhosis, but $25 \%$ of patients have no evident risk factor [3]. Liver cancer accounts for $13 \%$ of malignancy in Egypt with nearly 7,000 annual deaths [4].

HCC's high incidence in Egypt may be due to the highest levels of hepatitis $\mathrm{C}$ virus (HCV) spread and awareness of cirrhotic patient screening programs [5]. HCC has low prognosis and treatment choices. Early detection of HCC is very essential since surgical resection and/or ablation therapy are more effective when the tumor is small [6] so, screening systems aim to identify HCC at early stages [7].

Alpha fetoprotein (AFP) is a wellknown tumor marker. Its sensitivity varies from just $40 \%$ to $65 \%$. Its low sensitivity suggests the need for new HCC diagnostic biomarkers [8].

Golgi protein-73 (GP73) is a 400 amino acid, $73 \mathrm{kD}$ a trans-membrane glycoprotein in the cis-Golgi complex [9]. GP73 is a biomarker in advanced liver disease. GP73 levels are associated with various liver diseases such as hepatic fibrosis, liver cirrhosis [10], HCC [11] and HBV mediated acute on top of chronic liver failure $\left[\begin{array}{lll}12 & \& & 13\end{array}\right]$ and tumor metastasis prediction [14]. This study aimed to assess the value of serum GP73 in diagnosis of HCC patients. 


\section{PATIENTS AND METHODS}

The study was approved by the Ethics and Research Committee of the Benha Faculty of Medicine, Benha University, Egypt. Serum samples were collected from 60 patients with CLD who were subdivided into two groups: Group (I) consisted of 30 patients with primary HCC. Group (II) comprised 30 patients with hepatic cirrhosis and without any evidence of HCC and 20 healthy adults comprised the control group (Group III). An informed written consent was taken from all cases before their involvement in the study. HCC patients were diagnosed by abdominal ultrasound and confirmed by Triphasic C.T abdomen [15]. AFP was assayed by an enzyme immunoassay (EIA) kit (Roche Mannheim, Germany). Patient clinical /pathological data including age, sex, viral markers (HCV-Abs and HBsAg), alcohol consumption, biochemical liver profile, and AFP levels were recorded. The severity of liver disease was evaluated by the modified ChildPugh score [16] and MELD (model for end stage liver disease) score [17] and the updated MELD (uMELD) score [18]. Tumor characteristics were identified by abdominal US and the triphasic CT scan (tumor size, number, site, halo sign and neovascularization). Tumor staging was carried out using Okuda [19], CLIP (The Cancer of Liver Italian Program) [20] and Tokyo [21] staging systems.

\section{Blood sampling and biochemical assays:}

Fasting venous blood samples $(10 \mathrm{ml})$ were collected. A portion of blood was allowed to clot and centrifuged with 3500 grams for 5 minutes in order to isolate the serum used for the measurement of aspartate aminotransferase (AST), alanine-aminotransferase (ALT) and gglutamyl transpeptidase (GGT), total bilirubin, direct bilirubin, albumin, creatinine and glucose levels. The viral markers (HCV- Abs and HBsAg) were assessed using Abbott, Axyam (USA, supplied by Al kamal company). Using an enzyme-linked binding protein assay kit, serum AFP rates were assessed. All measurements were performed in duplicate according to the instructions of the manufactures. Serum aliquots were stored at $80^{\circ} \mathrm{C}$ until assayed and thawed immediately before measurements levels.

Serum Golgi Protein 73 assay using the commercially available enzyme-linked immunosorbent assay (ELISA).

\section{Statistical Analysis:}

Statistical package (SPSS, version 20.0) was used for data management. Descriptive statistics was presented as mean \pm standard deviations for continuous variables, number and percentage for categorical variables (frequency distribution). Unpaired student t-test (two sided) was used to test the significance of difference between the mean value of studied groups and chi-square test was used for comparison of categorical variables. The diagnostic value for each marker was assessed using sensitivity, specificity, positive (PPV) and negative (NPV) predictive values. Receiver operating characteristic curves (ROC) were constructed to assess the validity of the markers in predicting $\mathrm{HCC}$ by calculating the area under the curve (AUC). Pearson correlation test was used to identify the correlation between Golgi Protein 73 and different clinicopathological variables. The significance level was set at $\mathrm{P}<0.05$.

\section{RESULTS}

Table (1) showed the demographic features of the studied patients' groups. The mean age of HCC patients was $63.04 \pm 7.486$ years (ranging from 44 to 78 years). In liver cirrhosis patients, the mean age was $61.87 \pm 7.49$ years with a range between 48 and 74 years. There was no significant difference in the mean age, the sex of cases groups $(\mathrm{P}>0.05)$.

Concerning the residence, $80 \%$ of $\mathrm{HCC}$ cases had rural residence and a positive history of farming in $71.4 \%$ of HCC cases. HBV was detected in $3.3 \%$ of HCC cases and $6.7 \%$ of cirrhotic patients with no statistically significant difference between them. HCV was detected in $80 \%$ of HCC cases and $90 \%$ with no statistically significant difference $(\mathrm{P}=1.0)$. The severity of liver disease assessed by the Child - Pugh classifications among the studied patients showed that $3.3 \%$ of HCC patients were Child A, $26.7 \%$ of HCC patients were Child B and $70 \%$ were Child $\mathrm{C}$ without a significant difference. There was no statistically significant difference between the two groups as regard MELD score. Tumor imaging characteristics of HCC patients were shown in (Table 2). Abdominal triphasic $\mathrm{CT}$ revealed the dominant occurrence of $\mathrm{HCC}$ on top of cirrhosis $(100 \%)$ and a higher incidence of the focal lesion to be single (63\%), large $(40 \%)$ and right lobe location (59.3\%). 
The mean serum GP73 level was $(13.4 \pm 3.92$ $\mathrm{ng} / \mathrm{ml})$ in HCC group while it was $(1.9 \pm 1.19$ $\mathrm{ng} / \mathrm{ml})$ in cirrhotic group and $(0.66 \pm 0.49 \mathrm{ng} / \mathrm{ml})$ in control group. The mean serum GP73 level was significantly increase in HCC group when compared with cirrhotic and control groups $(\mathrm{P}=0.001 * *)$ as shown in (table 3$)$.

Table (1): Demographic Features of the studied patient groups:

\begin{tabular}{|c|c|c|c|}
\hline Characteristics & $\begin{array}{l}\text { HCC Patients } \\
\quad(n=30)\end{array}$ & $\begin{array}{c}\text { Liver Cirrhosis } \\
(n=30)\end{array}$ & $P$. value \\
\hline \multicolumn{4}{|l|}{ Age (years) } \\
\hline Range & $44-78$ & $48-74$ & \multirow{2}{*}{$>0.05$} \\
\hline Mean \pm SD & $63.04 \pm 7.486$ & $61.87 \pm 7.49$ & \\
\hline \multicolumn{4}{|l|}{ Gender } \\
\hline Male & $18(60 \%)$ & $17(56.7 \%)$ & \multirow{2}{*}{$>0.05$} \\
\hline Female & $12(40 \%)$ & $13(43.3 \%)$ & \\
\hline \multicolumn{4}{|l|}{ Residence } \\
\hline Urban & $6(20 \%)$ & $0(0.0 \%)$ & \multirow{2}{*}{$0.031 *$} \\
\hline Rural & $24(80 \%)$ & $30(100 \%)$ & \\
\hline \multicolumn{4}{|l|}{ Occupation } \\
\hline Farmer & $20(71.4 \%)$ & $28(93.3 \%)$ & \multirow{2}{*}{0.063} \\
\hline Non- farmer & $10(20 \%)$ & $2(6.7 \%)$ & \\
\hline \multicolumn{4}{|l|}{ Etiology } \\
\hline Smoking & $16(53.3 \%)$ & $10(33.3 \%)$ & 0.083 \\
\hline $\mathrm{HCV}$ & $24(80 \%)$ & $27(90 \%)$ & 1.0 \\
\hline $\mathrm{HBV}$ & $1(3.3 \%)$ & $2(6.7 \%)$ & 1.0 \\
\hline \multicolumn{4}{|c|}{ Severity of Liver disease Child- Pugh score } \\
\hline Child A & $1(3.3 \%)$ & $0 \quad(0 \%)$ & \multirow{3}{*}{0.54} \\
\hline Child B & $8(26.7 \%)$ & $8 \quad(21.4 \%)$ & \\
\hline Child C & $21(70 \%)$ & $22(78.6 \%)$ & \\
\hline \multicolumn{4}{|l|}{ MELD Score } \\
\hline Early $(6-11)$ & $6(19.6 \%)$ & $5(15.9 \%)$ & 0.66 \\
\hline Intermediate (12-18) & $11(36.5 \%)$ & $14(46.7 \%)$ & 0.43 \\
\hline Advanced (19-40) & $13(43.9 \%)$ & $11(37.4 \%)$ & 0.65 \\
\hline
\end{tabular}

*: Significant; SD: Standard deviation; HCC: hepatocellular carcinoma; HCV: Hepatitis C virus; HBV: Hepatitis B virus; MELD: Model for end stage liver disease.

Table (2): Tumor- computed tomographic findings and characteristics of the HCC Patient group.

\begin{tabular}{|l|c|c|}
\hline \multicolumn{1}{|c|}{$\begin{array}{c}\text { HCC Patients } \\
\text { Characteristics } \\
(\boldsymbol{n}=\mathbf{3 0})\end{array}$} & $16 / 12 / 2$ & $53.3 / 40 / 6.7$ \\
\hline $\begin{array}{l}\text { Tumor size } \\
<3 / 3-5 />5 \mathrm{~cm}\end{array}$ & $19 / 11$ & $63 / 37$ \\
\hline $\begin{array}{l}\text { No. of nodules } \\
\text { Single / } \text { or more }\end{array}$ & $18 / 2 / 10$ & $59.3 / 7.4 / 33.3$ \\
\hline $\begin{array}{l}\text { Site of Tumor } \\
\text { Right lobe/left lobe/both }\end{array}$ & $9 / 17 / 4$ & $28.6 / 57.1 / 14.3$ \\
\hline $\begin{array}{l}\text { Echogenicity } \\
\text { Hyperechoic/hypoechoic/isoechoic }\end{array}$ & & \\
\hline
\end{tabular}


Table (3): AFP and GP73 values in the studied groups.

\begin{tabular}{|l|c|c|c|l|}
\hline Marker & $\begin{array}{c}\text { Group I HCC } \\
(\boldsymbol{N}=\mathbf{3 0}) \\
\text { Mean } \pm \text { SD }\end{array}$ & $\begin{array}{c}\text { Group II cirrhosis } \\
(\boldsymbol{N}=\mathbf{3 0}) \\
\text { Mean } \pm \text { SD }\end{array}$ & $\begin{array}{c}\text { Group III control } \\
(\boldsymbol{N}=\mathbf{2 0}) \\
\text { Mean } \pm \text { SD }\end{array}$ & $\boldsymbol{P}$ value \\
\hline GP73 $(\mathbf{n g} / \mathbf{m L})$ & $13.4 \pm 3.92$ & $1.9 \pm 1.19$ & $0.66 \pm 0.49$ & $\begin{array}{l}\mathrm{P} 1=0.001^{* *} \\
\mathrm{P} 2=0.001^{* *} \\
\mathrm{P} 3=0.001^{* *}\end{array}$ \\
\hline AFP $(\mathbf{n g} / \mathbf{m L})$ & $368.78 \pm 328.25$ & $43.0 \pm 66.91$ & $1.5 \pm 4.09$ & $\begin{array}{l}\mathrm{P} 1=0.001^{* *} \\
\mathrm{P} 2=0.001 * * \\
\mathrm{P} 3=0.008^{* *}\end{array}$ \\
\hline
\end{tabular}

** Highly significant, GP73: Golgi Protein 73, AFP: Alpha-fetoprotein.

Table (4): AFP and GP73as markers for HCC.

\begin{tabular}{|c|ll|cc|cl|}
\hline Test & Cut off & Sensitivity \% & \multicolumn{2}{|c|}{ Specificity \%PV \% } & NPV \% & AUC \% \\
\hline GP73 (ng/mL) & 5.8 & 95 & 83.3 & 79.2 & 96.2 & 0.931 \\
AFP ng/mL & 19.85 & 90 & 66.7 & 64.3 & 90.9 & 0.762 \\
\hline
\end{tabular}

PPV:positive predictive value,NPV:negative predictive value,AUC:Area under the curve.

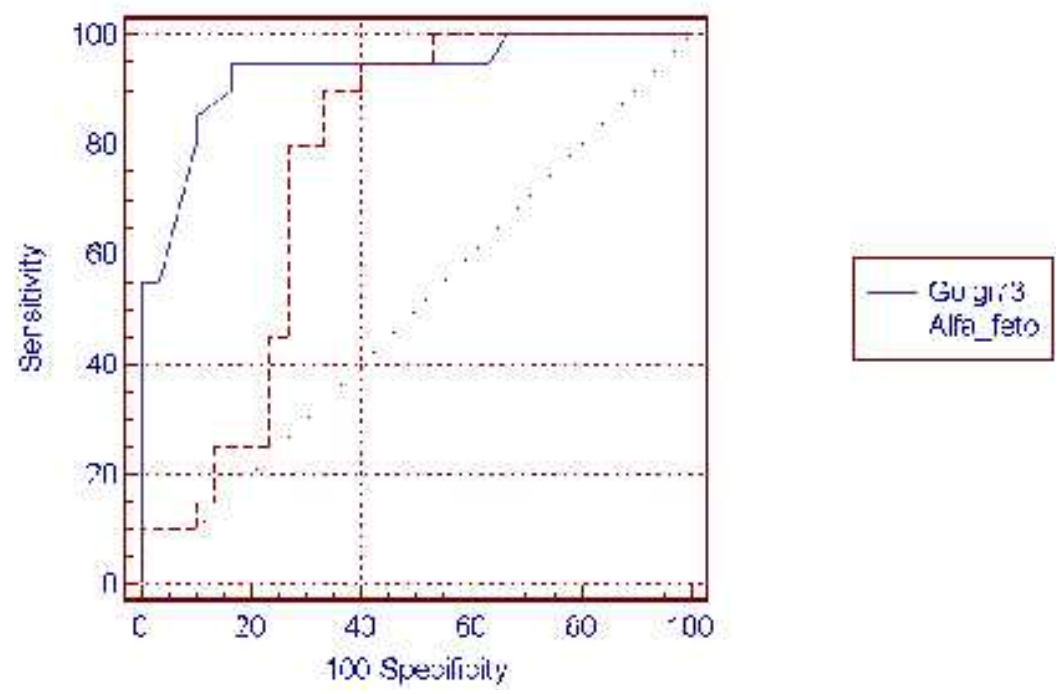

Figure (1): ROC curve between HCC and non HCC as regard GP-73 and AFP.

Table (5): Correlations between GP73 and different classifications of HCC group.

\begin{tabular}{|l|c|c|}
\hline \multicolumn{1}{|c|}{ GP73 } & r & $\boldsymbol{P}$ \\
\hline Child & 0.2 & 0.19 \\
\hline MELD & -0.096 & 0.696 \\
\hline uMELD & -0.043 & 0.863 \\
\hline Okuda score & 0.3755 & $0.041^{*}$ \\
\hline CIIP score & 0.565 & $0.001^{* *}$ \\
\hline Tokyo & 0.352 & 0.056 \\
\hline
\end{tabular}

There was a positive correlations between GP73 level and Okuda staging, Okuda score and CIIP score and no correlations with number and size of the tumor, Child, MELD, uMELD, CLIP stage and Tokyo stages.

\section{DISCUSSION}

Hepatocellular carcinoma (HCC) is one of the main complications of liver cirrhosis, displaying a high incidence in Egypt, which may be the result of high prevalence of $\mathrm{HCV}$ and $\mathrm{HBV}$ infections [22].
Golgi Protein 73 (GP73) is considered to be a serum marker for liver disease; Gp73 is expressed minimally in healthy hepatocytes but significantly expressed in chronic hepatitis and liver cirrhosis [10]. A circulating form of GP73 is present in the serum of patients with $\mathrm{HCC}$ [23]. These data indicate that serum GP73 is a promising serum marker in the diagnosis of

El-Toukhy et al., Afro-Egypt J Infect Endem Dis 2020;10(2):294-300

https://aeji.journals.ekb.eg/

http://mis.zu.edu.eg/ajied/home.aspx 
HCC. The serum GP73 is considered the only independent factor in prediction of hepatic inflammation and fibrosis in a multivariate regression analysis. So, GP73 expression could be used as a prognostic marker for CLD [25].

In the present study there was a very highly significant increase in the mean serum GP73 level in HCC group when compared with cirrhotic and control groups. These findings agreed with the results of Morota et al.[26] and Zhou et al.[27] who showed a significant increase in serum GP73 in HCC patients in comparison with both benign liver diseases or the healthy controls and has a better diagnostic performance than AFP for HCC detection. Also, GP73 is a valuable serum marker for follow up of HCC patients after surgical resection.

In this study, the level of GP73 did not show significant difference as regard the number or the size of hepatic focal lesions in HCC patients. This came in agreement with Ozkan et al. [28] and Tian et al. [29] who reported the same results.

The study also revealed that there was no correlation between GP73 concentrations and Child's stage. This was in agreement with Mao et al. [30], who recorded the same result.

Concerning the sensitivity and specificity of AFP; the sensitivity and specificity of AFP at cutoff value $>19.85 \mathrm{ng} / \mathrm{ml}$ the sensitivity was $90 \%$, the specificity was $66.7 \%$ this was in agreement with Tian et al.[29], sensitivity was 95\%, specificity was $47 \%$ and with Shi et al.[31] sensitivity was $75 \%$, specificity $75 \%$. Moreover, Gp73 at cutoff value $5.8 \mathrm{ng} / \mathrm{ml}$ the sensitivity, specificity and diagnostic accuracy were $(95 \%$, $83 \%, 93 \%$ ), respectively. Hu et al.[32] recorded that the sensitivity $77 \%$, specificity $84 \%$ at cutoff value $7.4 \mathrm{ng} / \mathrm{ml}$, Marrero et al.[24] stated that $70 \%$ sensitivity, $86 \%$ per at a cutoff value $10 \mathrm{ng} /$ $\mathrm{ml}$, Shi et al.[31] noticed that sensitivity $98 \%$, specificity $95 \%$ at a cut of value $100 \mathrm{ng} / \mathrm{ml}$.

GP73 is not expensive valuable diagnostic marker for HCC and can improve its detection and management and can be used in screening of $\mathrm{HCC}$ due to its high sensitivity.

\section{CONCLUSION}

According to this study, GP73 is elevated in patients with HCC more than cirrhotic, GP73 was found to have higher sensitivity, specificity and diagnostic accuracy when compared to AFP in HCC patients and can be used in diagnosis and screening of HCC.

Funding: None

\section{Conflicts of interest: None}

Ethical Approval: A written informed consent was taken from all included patients, and the study was approved by the Ethical Committee of our institution.

\section{REFERENCES}

1. Mittal S, El-Serag HB. Epidemiology of hepatocellular carcinoma: Consider the Population. J Clin Gastroenterol 2013; 47 Suppl:S2-6.

2. Dhanasekaran R, Limaye A, Cabrera R. Hepatocellular Carcinoma: current trends in worldwide epidemiology, risk factors, diagnosis, and therapeutics. Hepat. Med. Journal 2012; (4): 19-37.

3. Petrick JL, Kelly SP, Altekruse SF, McGlynn KA, Rosenberg PS. Future of Hepatocellular Carcinoma Incidence in the United States Forecast Through 2030. J Clin Oncol 2016; May 20.34 (15):1787-94.

4. Hatzakis A1, Van Damme P, Alcorn K, Gore C, Benazzouz M, Berkane S, et al. The state of hepatitis $\mathrm{B}$ and $\mathrm{C}$ in the Mediterranean and Balkan countries: report from a summit conference. J Viral Hepat 2013; Aug 20 Suppl 2:1-20.

5. Attwa, M.H. and El-Etreby, S.A. Guide for diagnosis and treatment of hepatocellular carcinoma. World Journal of Hepatology 2015 ; 7(12):1632-1651.

6. Bolondi L, Gaiani S, Celli N, Golfieri R, Grigioni WF, Leoni S, et al. Characterization of small nodules in cirrhosis by assessment of vascularity : the problem of hypovascular hepatocellular carcinoma. Hepatology 2005; 42(1) :27-34.

7. Colagrande $\mathrm{S}$, Inghilesi $\mathrm{AL}$, Aburas $\mathrm{S}$. Challenges of advanced hepatocellular carcinoma. World J Gastroenterol 2016; 22: 7645-7659.

8. Morris KL, Tugwood JD, Khoja L, Lancashire M, Sloane R, Burt D, et al. Circulating 
biomarkers in hepatocellular carcinoma. Cancer Chemotherapy and Pharmacology 2014; 74:323-332.

9. Kladney RD, Bulla GA, Guo L, Mason AL, Tollefson AE, Simon DJ, et al. GP73, a novel Golgi-localized protein up regulated by viral infection. Gene 2000; 249: 53-65.

10. Iftikhar R, Kladney R, Havlioglu N, SchmittGräff A, Gusmirovic I, Solomon $\mathrm{H}$, et al. Disease and cell-specific expression of GP73 in human liver disease. Am J Gastroenterol 2004; 99:1087-1095.

11. Zhao Y, Wang M, Cui C, Zhang L, Liao F, Li H, $\mathrm{Wu} \mathrm{X}$. Significance of combined tests of serum golgi glycoprotein 73 and other biomarkers in diagnosis of small primary hepatocellular carcinoma. Cancer Biomark 2015; 15(5):677-83.

12. Wei H, Li B, Zhang R, Hao X, Huang Y, Qiao Y, et al. Serum GP73, a marker for evaluating progression in patients with chronic $\mathrm{HBV}$ infections. PLoS One 2013; 8(2):e53862.

13. Qiao Y, Chen J, Li X, Wei H, Xiao F, Chang L, et al. Serum gp73 is also a biomarker for diagnosing cirrhosis in population with chronic HBV infection. Clin Biochem 2014; 47(1617):216-22.

14. Liu Y, Zhang X, Zhou S, Shi J, Xu Y, He J, et al. Knockdown of Golgi phosphoprotein 73 blocks the trafficking of matrix metalloproteinase-2 in hepatocellular carcinoma cells and inhibits cell invasion. J Cell Mol Med 2019; 23(4):2399-2409.

15. Bruix J, Sherman M. Management of hepatocellular carcinoma: an update. Hepatology 2011; 53:1020-1022.

16. Pugh RN, Murray-Lyon IM, Dawson JL, Pietroni MC, Williams R. Transection of the oesophagus for bleeding oesophageal varices. Br. J. Surg. 1973; 60: 646-9.

17. Kamath PS, Wiesner RH, Malinchoc M, Kremers W, Therneau TM, Kosberg CL, et al. A model to predict survival in patients with endstage liver disease. Hepatology 2001; 33:46470 .

18. Sharma P, Shaubel DE, Sima CS, et al. Reweighting the model for end-stage liver disease score components. Gastroenterology 2008; 135: 1575-1581.
19. Okuda K, Ohtsuki T, Obata H, Tomimatsu M, Okazaki N, Hasegawa H, et al. Natural history of hepatocellular carcinoma and prognosis in relation to treatment. Study of 850 patients. Cancer 1985; 56(4): 918-928.

20. CLIP investigators. A new prognostic system for hepatocellular carcinoma: a retrospective study of 435 patients: the Cancer of the Liver Italian Program (CLIP) investigators. Hepatology 1988; 28(3): 751-755.

21. Tateishi R, Yoshida H, Shiina S, Imamura H, Hasegawa K, Teratani T, et al. Proposal of a new prognostic model for hepatocellular carcinoma: an analysis of 403 patients. Gut 2005; 54: 419425.

22. Gomaa AI, Hashim MS, Waked I. Comparing staging systems for predicting prognosis and survival in patients with hepatocellular carcinoma in Egypt. PLoS One 2014 Mar 6;9(3):e90929.

23. Block T, Comunale M, Lowman M, Steel LF, Romano PR, Fimmel C, et al. Use of targeted glycoproteomics to identify serum glycoproteins that correlate with liver cancer in woodchucks and humans. Proc Natl Acad Sci USA 2005; 102: 779-784.

24. Marrero J, Romano PR, Nikolaeva O, Steel L, Mehta A, Fimmel CJ, et al. GP73, a resident Golgi glycoprotein, is a novel serum marker for hepatocellular carcinoma. J Hepatol 2005; 43:1007-1012.

25. Xu Z, Liu L, Pan X, Wei K, Wei M, Liu L, et al. Serum Golgi Protein 73 (GP73) is a Diagnostic and Prognostic Marker of Chronic HBV Liver Disease. Medicine (Baltimore) 2015; 94(12): e659.

26. Morota K, Nakagawa M, Sekiya R, Hemken PM, Sokoll LJ, Elliott D, et al. A comparative evaluation of Golgi protein 73 fucosylatedhemopexin, alfa fetoprotein and pivika-11 in the serum of patients with chronic hepatitis, cirrhosis, and hepatocellular carcinoma. Clinc Chem Lab Med 2011; 49:711718.

27. Zhou Y, Yin X, Ying J, Zhang B. Golgi Protein 73 versus alpha fetoprotein as a biomarker for hepatocellular carcinoma: a diagnostic metaanalysis. BMC Cancer 2012 Jan 16;12:17. 
28. Ozkan H, Erdal H, Tutkak H, Karaeren Z, Yakut M, Yüksel O, et al. Diagnostic and prognostic validity of Golgi protein 73 in hepatocellular carcinoma. Digestion 2011;83(1-2):83-8.

29. Tian L, Wang Y, Xu D, Gui J, Jia X, Tong H, et al. Serological AFP /Golgi protein 73 could be anew diagnostic parameter of hepatic disease. Int J Cancer 2011; 7: 6 -7.

30. Mao Y, Yang $\mathrm{H}, \mathrm{Xu} \mathrm{H}$. Golgi protein 73 (GOLPH2) is a valuable serum marker for hepatocellular carcinoma. Gut 2010; 59:16871693.

31. Shi Y, Chen J, Li L, Sun Z, Zen L, Xu S, et al. A study of diagnostic value of Golgi protein Gp73 and its genetic assay in primary hepatic carcinoma. Techol Cancer Res Treat 2011; 10:287-294.
32. Hu L, Li L, Xie H, Gu Y, Peng T. The Golgi localization of GOLPH2 (GP73/ GOLM1) is determined by the transmembrane and cytoplasmic sequences. PLOS One 2011; 6: 28207.

33. Wang L, Yao M, Pan LH, Qian Q, Yao DF. Glypican-3 is a biomarker and a therapeutic target of hepatocellular carcinoma. Hepatobiliary Pancreat Dis. Int 2015; 14(4):361-6. 